\title{
Violence in the American Imaginary: Gender, Race, and the Politics of Superheroes
}

\author{
MENAKA PHILIPS Tulane University, United States
}

$W$

hat does the superhero - an icon of the American imaginary - communicate about the politics of violence? Responding to nationwide protests of police brutality in 2020, law enforcement officers adopted the skull logo of The Punisher, an exceptionally violent fictional vigilante. That adoption signals what I call the privilege of violence: the force individuals may deploy based on normative expectations concerning gender and race. Comparing Marvel-Netflix productions including The Punisher series, I identify three modes of violence in operation: the unrestricted rage of a white male vigilante, the vulnerability of a feminist heroine, and the sacrificial control of a Black male hero. The article demonstrates the gendered and racialized conditions under which heroic violence is rendered legitimate to American audiences. As I conclude, Punisher's unrestricted violence valorizes white male grievance, and this is precisely what appeals to armed agents of the American state.

Imagination is the beginning of creation. You imagine what you desire, you will what you imagine, and at last, you create what you will-Bernard Shaw

On February 23, 2020, Ahmaud Arbery was chased down and fatally shot by three white men, one of whom was a former officer with the Glynn County Police Department (Rojas, Fausset, and Kovaleski 2020). Less than a month later, on March 13, Breonna Taylor was gunned down in her home while asleep, by three, plainclothes Louisville Metro police officers. And on May 25, 2020, George Floyd was suffocated to death by ex-Minneapolis police officer Derek Chauvin. Theirs were not the first Black lives lost to racially charged violence, but occurring in the span of four months, their deaths reignited the Movement for Black Lives on a scale not previously seen across America (Buchanan, Bui, and Patel 2020).

Notably, the world of superheroes merged with these events. In the midst of sustained protests organized in response to the killings of Arbery, Taylor, and Floyd, some law enforcement officers and even entire police departments began displaying the skull logo of Marvel's Punisher-a fictional vigilante known for his extreme violence (Cronin 2020). Adopted outright, and sometimes retrofitted to feature a black and white American flag and a blue line, the appearance of The Punisher skull on police vests, cars, and social media posts is not only a reaction to the protests for racial justice sweeping the nation but also a statement about the status and self-understanding of law enforcement personnel in the face of renewed national scrutiny. And it is not the first time The Punisher has been appropriated by American security forces for that reason.

Menaka Philips (D), Assistant Professor, Department of Political Science, Tulane University, United States, mphilip1@tulane.edu.

Received: July 10, 2020; revised: January 10, 2021; accepted: July 26, 2021. First published online: September 13, 2021.
In 2017, The Punisher skull was decaled onto the official vehicles of a Kentucky police department along with the slogan "Blue Lives Matter" (Campbell 2017). Two years later the St. Louis Police Officer's Association encouraged members to adopt a version of the emblem as a sign of support for officers who were under investigation for publishing "a range of concerning images and statements on social media" (Balk 2019; see Figure 1). In a letter to members, association president Ed Clark noted that the "Blue Line Punisher" had "been widely embraced by the law enforcement community as a symbol of the war against those who hate law enforcement. It's how we show the world that we hold the line between good and evil" (Clark 2019). More bluntly, Navy Seal Chris Kyle, popularly known as the "American Sniper," outfitted his field unit in Iraq with the Punisher skull to announce, "We're here and we want to fuck with you" (Kyle, McEwen, and DeFelice 2013, 231).

Why do armed units of the American state identify with this outlaw legend of the comic book genre? ${ }^{1}$ I argue that these appropriations of The Punisher constitute a fundamentally political act to which scholars should pay close attention. The Punisher-a character defined by his brutality - participates in the privilege of violence. By this I mean the force or coercion particular individuals may deploy based on normative expectations concerning gender and race. This privilege of violence can be difficult to see, in part because it operates in the interstices of broader forms of structural violence-rooted in the everyday workings of social, economic, and legal institutions and practices - which impairs the opportunities and experiences available to certain populations (Galtung 1969). The privilege of violence, however, operates through individuals to delineate the forms of violence they can use in response to experiences with loss, harm, and injustice.

\footnotetext{
${ }^{1}$ The Punisher character was created by Gerry Conway, and first introduced by Marvel Comics in 1974.
} 


\section{FIGURE 1. "Blue Line Punisher" Profile Picture on the St. Louis Police Officer's Association Public Facebook Page}

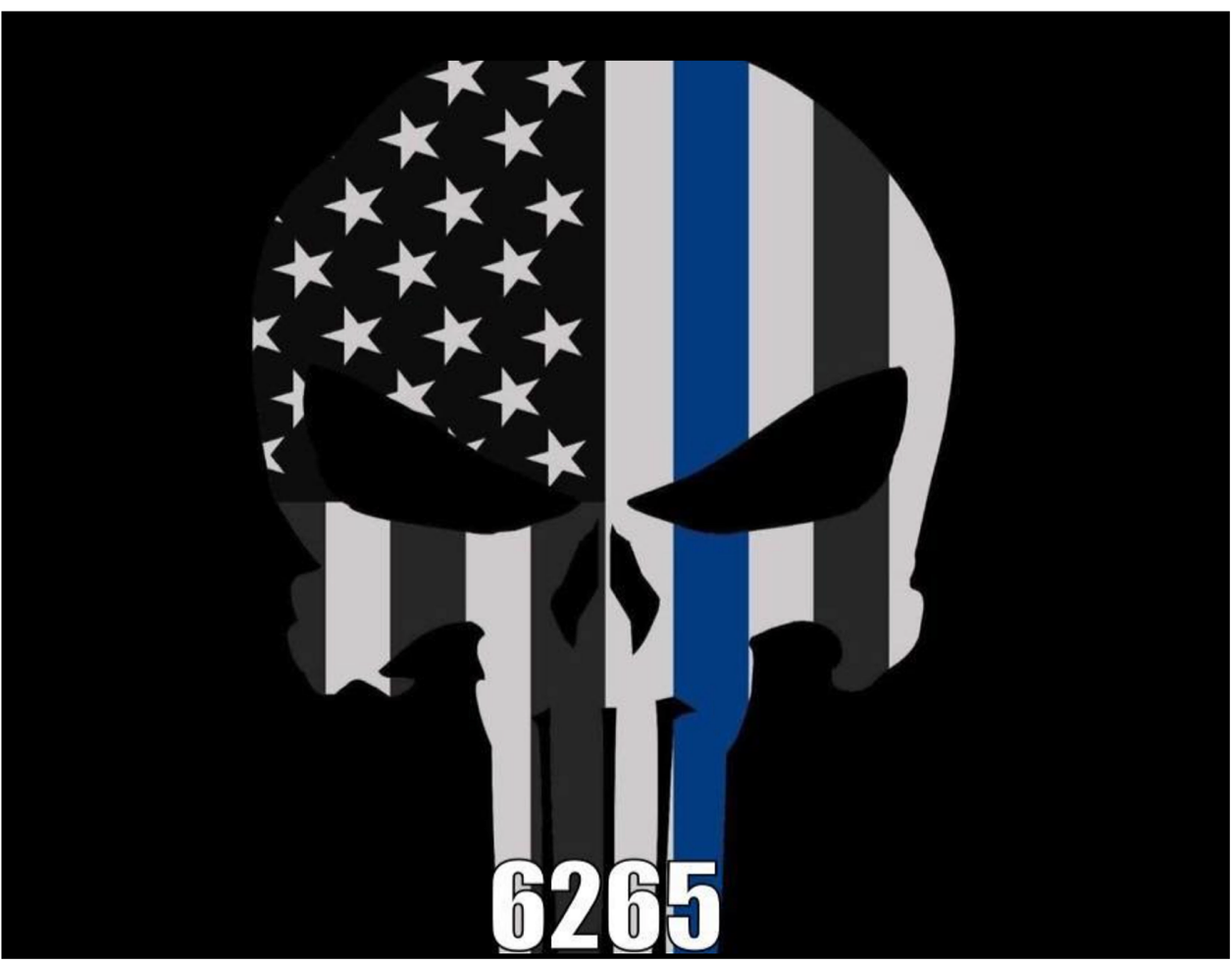

Note: Screenshot by Author, available at https://www.facebook.com/stlouispolice.officersassociation/photos/a.337137539825055/ 1026869934185142.

As defined here, privileged violence identifies not only who can use violence but also how they can do so in ways that will be recognized as legitimate. The forms of agency generated through privileged violence are unique also because the legitimate use of force is traditionally understood to be under the purview of the state. But the privilege of violence is more diffuse, extending to the persons society marks as natural enforcers of justice and order. And nowhere is that clearer than in the narratives of superheroes, figures whose agency as heroes is defined not only by their powers but also by their enactments of violence, often as surrogates for a weak or ineffective state (Burke, Gordon, and Ndalianis 2019). Yet, for state agents like those noted above, drawing on the outlaw symbolism of The Punisher signals a defense of the privilege of violence they assume in excess of what they are formally authorized to use. That symbolic defense, moreover, is mobilized precisely in those moments when unequal deployments of force are exposed or challenged.

\section{THE PRIVILEGE OF VIOLENCE}

Claudia Rankine observes the history and "normalcy" of white male privilege in America is far from universally recognized (Rankine 2019). A 2017 Pew study found that where $68 \%$ of Black Americans thought white people benefitted a great deal from racial privilege, only $16 \%$ of white Americans agreed (Oliphant 2017). This disparity bears consideration when examining how violent acts are interpreted in American society. Scholars Anthea Butler (2015) and Ibram X. Kendi (2020) observe that media coverage following shootings committed by white men like Dylan Roof and Kyle Rittenhouse often work to humanize shooters and define their actions in terms of mental illness, past injury, even heroism, while nonwhite victims of white male violence are described as being "no angels," their actions and characters held to greater scrutiny (Eligon 2014). Thus, the claim that white men are possessed of a greater privilege to violence is, troublingly, a controversial one, given its complicated resonance within American society.

Turning to cinematic portrayals of violence through the superhero, my objective is to offer an additional vantage point from which questions about violence and its justification can be examined in political science. Work in gender and critical race studies is especially informative about how structures shape broader social, legal, and political violence in the American polity (Asad 2010; Fischel 2017; Howard-Woods, Laidley, and Omidi 2017; Rogers 2020; Threadcraft 2016). That work permeates both scholarly and public responses to gender-based violence, racism, and police brutality in 
recent years, particularly in the wake of the \#MeToo movement, Ferguson, Charlottesville, and the global reaction to the recorded police killing of George Floyd. On the subject of race, existing studies illustrate James Baldwin's observation that "in the United States, violence and heroism have been made synonymous, except when it comes to blacks" (Baldwin 1962).

But the American imaginary reveals a more complex - though equally fraught-understanding of heroic violence than this observation suggests. The superhero genre does not disqualify historically marginalized groups from engaging in violence, but it does modify the forms their heroic violence can take. In the imaginary world of superheroes and vigilantes, from which law enforcement officers draw their Punisher icon, violence is both embraced and celebrated. As a result, who has permission to use violence, and how, is rendered starkly visible in these works of fiction. That permit is especially clear in comparative perspective. Notably, The Punisher has been read as a critical interrogation of the costs of American militarism and toxic masculinity (Illing 2017). But when viewed alongside other popular superheroes in his world, The Punisher's indiscriminate access to violence is unmistakably privileged by his status as a white man.

To expose the privilege of violence denoted by appropriations of The Punisher, I provide a close comparative reading of three prominent popular cultural texts: Marvel's Netflix-produced series The Punisher, Jessica Jones, and Luke Cage. ${ }^{2}$ Though part of the same universe as the studio's other productions, like Daredevil and Iron Fist, these series were uniquely pitched as critical commentaries on social issues in the American polity. ${ }^{3}$ The Punisher series (2017), whose producer Steve Lightfoot interviewed and cast American veterans as veterans on the show, set out to examine the traumas of war, loss, and toxic masculinity by highlighting the effects of violence on its male protagonist, Frank Castle (aka The Punisher). Jessica Jones (2015), developed by Melissa Rosenberg, centers the consequences of gender-based violence in its unflinching focus on sexual assault, interpersonal abuse, and recovery. And Luke Cage (2016), helmed by Cheo Hodari Coker, addresses race in America through its depictions of systemic racism, a focus given a symbolic twist through its eponymous protagonist - a bulletproof Black man. Acclaimed for their diverse production teams and storylines, all three texts inventively expose structures of violence in American society, from militarism and trauma to gender and racial marginalization.

The article makes three critical contributions to discussions of violence in American politics. The first is to

\footnotetext{
${ }^{2}$ The article focuses on the debut seasons of each series, as I am interested in the role the origin story plays in introducing audiences to the protagonists. Rendering them legible as "heroes" in the first place is critical for the initial audience buy-in to the series, which lays the foundation for character arcs in subsequent seasons.

${ }^{3}$ Recent serialized productions like HBO's Watchmen and MarvelDisney's The Falcon and the Winter Soldier were similarly presented (Adams 2021; Braxton 2019).
}

introduce a conceptual schematic for evaluating the types of violence we see depicted in these three cultural texts. My claim is not that, as a white man, The Punisher has access to violence while Jones and Cage are prohibited from its use. As scholars have observed, that kind of license/prohibition dichotomy demarcates whose violence is granted the "moral high ground" as a principled response to external threats and whose is, by contrast, delegitimized (Anderson 2016, 4; see also: McCluskey 1992, 282). The argument on offer here, however, complicates such studies by looking at the conditions under which the title to violence is granted to historically marginalized groups.

In the context of superheroes, violence is expected not only of the "bad guys" but of the "good guys" as well. In spaces where violence is expected of individuals other than white men, what forms must it take to be recognized as valid? As we shall see, the superhero narratives noted above are each animated by gendered and racial conditions upon the forms of violence their different protagonists can enact. Those narratives reveal the nuanced ways in which gender, race, and violence intersect to produce visions of heroism in the public sphere. Examination of these popular texts, I argue, shows that violence is not the sole purview of white men; rather, it is a resource differentially distributed within a caste system that polices how violence is deployed in constructions of the hero/villain, friend/ enemy, patriot/seditionist. Turning to narrative constructions of the superhero illustrates that the privilege of violence is not simply about access to force, but about variations in the performance and legitimation of force. I suggest that those variations construct three different modes of violence available to our heroic protagonists. For the character Jessica Jones, her violence must appear reluctant, trauma-driven, and tethered to a performance of gendered vulnerability. Luke Cage's violence is conditioned by sacrifice, disciplined by the racialized politics of respectability expected by white audiences. In contrast to both, Frank Castle's violence is unrestricted and explosive in its expression.

Second and following, the article illustrates what the privilege of violence variously depicted through these characters reflects about the boundaries of the American imaginary, as a mirror for American life. As I argue here, the privilege of violence remains strikingly immune to transformation even in creative spaces where we have room to demand it. That is because while all three series take an explicitly critical view of broader structures of violence from militarism to systemic racism, each also reinforces the privilege of violence through the modes of force their protagonists can deploy. Failing to attend to these narrative deployments of violence can thus mask the stratified ways in which heroic violence is interpreted and justified. What the forms of violence depicted in these popular cultural texts reveal is the extent to which the American imaginary replicates, even as it can creatively rethink, the conditions of violence in American society.

Finally, the article highlights and expands on important connections between work in political science and studies of popular culture, wherein concerns about 
issues of violence, gender, race, and their representations intersect. Attention to popular narratives constitutes an undervalued resource for political scientists. But, as prominent artifacts of popular culture, superhero stories and symbols can communicate political messages, identities, and principles, and we cannot ignore the fact that people value and variously appropriate these symbols every day.

In short, the harms and inequities the three popular texts examined here set out to challenge are inadvertently reproduced in the forms of violence their heroes engage in. That reproduction reveals the insidious character of privileged violence in American society: the very hierarchies these texts try to deconstruct nevertheless penetrate their efforts to critically respond to and reimagine the dynamics of violence in American life. In so doing, these stories point at the rootedness of privileged violence in the American imaginary, to capture the challenges facing efforts to fundamentally expose and reform the politics of violence in American society.

\section{POLITICS AND POPULAR CULTURE}

Popular culture is a valuable resource for political study. It is a space that "significantly affects how the average citizen understands and engages with her or his political environment" and "through which we understand and interact with our (and other) communities" (Dorzweiler 2017, 151, 139). Popular culture can thus "be a foundational text or demarcation to measure cultural attitudes," as well as their shifts and possibilities (Vaughn and Goren 2013, 6). Yet, Nick Dorzweiler observes that the discipline's attention to popular culture has been relatively thin and notably absent from mainstream political science journals. ${ }^{4}$ But scholars of politics ought to be cautious about dismissing from consideration the everyday texts and images with which most people interact. Indeed, the lack of engagement with popular culture in political science is striking given the field's recognition of the now classic plays and tragedies of antiquity, works of popular culture in their own time (Grig 2016). ${ }^{5}$ In forgoing the popular works of our time, we risk ignoring resources that address the daily lives and interests of the very constituency that defines the study of politics: the public.

\section{The Superhero as Symbol}

Consider how widely consumed the superhero is. The transmedia mobility of the superhero genre means that it is no longer a niche focus of comic books. Rather, the superhero has become almost universally visible,

\footnotetext{
${ }^{4}$ References to popular culture appear only once in the American Political Science Review as of 2017 and not at all in the American Journal of Political Science between 1973-2010 (Dorzweiler 2017, 139).

${ }^{5}$ I am indebted to Emily Anderson and Jill Frank for pointing out this tension.
}

spanning a multibillion-dollar industry that includes comics, films, television shows, and beyond. More than half of Americans aged 18-34 have seen at least one film in the Marvel Cinematic Universe, making it the highest earning film franchise of all time (Watson 2019). In an era where seemingly "everything feels broken" notes one journalist, "superheroes are indestructible" (Fennessey 2017).

Direct engagement with popular texts like that of the superhero creates opportunities to develop crossdisciplinary conversations about those texts on issues of political import. Stan Lee, one of the titans of the American comic, defines a superhero as "a person who does heroic deeds and has the ability to do them in a way that a normal person couldn't" (Lee 2013,115). As both part of and removed from society, the superhero follows the tradition of the Hollywood Western to represent "dimensions of an American self-understanding of great relevance to the question of the nature of the political in the American imaginary" (Pippin 2010, 141). And like the Western, superhero narratives have always been intentionally political, providing "a natural place for conflicts around citizenship to play out" (Wanzo 2009, 343).

As comic scholars argue, Superman's quest for justice might model a vision of global citizenship rooted in American imperialism (Nama 2013,253), as much as an "assimilationist fantasy" of the immigrant story in response to "American fascism in the 1930s" (Schlam 2001, 98). The transformation of billionaire tycoons like Bruce Wayne and Tony Stark into Batman and Iron Man occurs in response to "the most toxic real world social issues that America had to offer," from political corruption and crime, to the politics of war profiteering (Nama 2013, 256). And Jeffrey Brown points out that while superheroes often represent "an acceptable, albeit obviously extreme, model of hypermasculinity," this genre convention has had particular representative implications for Black superheroes like Luke Cage or Black Panther, who emerged during the era of Blaxploitation media (Brown 2013, 269). As popular engagements with social issues and identities, superhero stories therefore marry the "absurd and surreal" to "the concrete and tangible" (Coates 2016a). They produce superhuman narratives that are driven by distinctly human questions.

Comics are also "highly ego-evolving for many readers, adult and children," cultivating "reading communities" and significant identity-based attachments (McAllister, Sewell, and Gordon 2001, 4). As Jonathan Cohen observes, the study of audience identification has been central to media research in part because it shows us how "audience members experience reception and interpretation of the text from the inside, as if the events were happening to them" (Cohen 2001, 245). The backlash films and comics have received for changing the racial, ethnic, or gender identity of characters historically depicted as white and/or male is an instructive reminder of the possessive intimacy audiences build with these texts and characters (Peppard 2019). In fact, the public's interaction with the popular narratives of the superhero present 
opportunities to examine how dominant social and political norms about identity are interpreted and disseminated (Burke, Gordon, and Ndalianis 2019). The superhero genre has worked as both a mimic and critic, at times reinforcing dominant norms, and at others facilitating critical reflections about them. It has thus become a dynamic space within which issues of identity and representation are raised.

Noting this, Ta-Nehisi Coates observes that superheroes are part of an American mythology: "They're our Greek gods. And it's in our pantheon that the only people with power ... in our pantheon are straight, white dudes-that says something about how we imagine ourselves" (Coates 2016b). But reimagining that pantheon is also what drove acclaimed films like Black Panther and Wonder Woman, as well as the Marvel-Netflix series discussed here. Their interventions point to the ways in which superhero stories can hold representative possibilities for people who have had limited space in social and political discourses that traditionally center white and masculine perspectives (Haslem, MacFarlane, and Richardson 2019).

In these ways, superheroes have evolved to depict new and conflicting iterations of American identity and the pathologies, fears, and hopes that shape them: "superheroes-by their very nature as cultural representations of superempowered individuals-mirror, comment on, and sometimes parody the kinds of ideas, movements, policies, and institutions that interest political scientists" (Costello and Worcester 2014, 85). How superhero symbols are adopted and deployed in popular culture constitutes acts of identity creation and disruption, acts that are expressly political in their representative effects.

As these characters are also defined by extraordinary abilities to use force, their stories communicate much about how the politics of violence are interpreted and rationalized in the public sphere. More particularly, as I argue in the remainder of this article, texts like The Punisher, Jessica Jones, and Luke Cage offer compelling insights into the organization of violence in American life-both imagined and real.

\section{THE VIOLENCE WE IMAGINE}

Frank Castle (The Punisher) was the first of the three characters examined here to appear on a Marvel Netflix show (debuting on Daredevil in 2016). But his standalone series The Punisher aired in 2017, after Jessica Jones debuted in 2015, and Luke Cage in 2016. Marvel never intended to create a Netflix series around The Punisher character. It was the vigilante's popularity with audiences that led the studio to pursue one. Even so, despite their separate releases and storylines, all three narrative arcs intersect in their tripartite engagements with structures of violence in American society and were widely praised for doing so.

Where The Punisher examines the costs of statesanctioned violence in the context of war, Jessica Jones and Luke Cage confront the violent consequences of gender and racial inequities. Yet, despite these conscious efforts to root out and challenge structures of violence, all three of their protagonists replicate gendered and racialized modes of violence through their own actions. In what follows, I outline the protagonists' relationship to violence, before turning to the modes of violence they adopt in response to experiences of loss, harm, and injustice.

\section{The Citizen-Warrior}

Frank Castle is a white man without any superpowers. His extraordinariness is marked by a striking, though human, ability to kill and a remarkable ability to survive. A former soldier, Castle was stationed in Afghanistan with a covert assassination unit that was, unbeknownst to him, operating an illegal drug smuggling ring. Under the false impression that Castle planned to reveal their activities, the unit's commanding officer and others involved orchestrate the murder of Castle, his wife, and two children - a hit that Castle survives. It is this incident, the murder of his family on the order of military officials, that creates his alter ego: The Punisher. His primary mission becomes vengeance.

As The Punisher, Castle effectively continues to operate as an assassin, though no longer under the auspices of the American military. Rather the trauma and betrayal Castle experiences as a soldier inform his vigilantism as a civilian. His actions are shaped by what was done to his family by corrupt state agents and, later, by a determination to exact "justice" from individuals or organizations he deems criminal. Positioned against the seedy power of officials both high and low, Castle's violent vigilantism works as a critical commentary on the state and its justice system as a whole.

But after his extended battle against corrupt officials, we also find Castle at odds with the identity that he has learned to inhabit. In that struggle, Castle's character offers a critical view of what Robert Nye calls the "citizen warrior." As Nye argues, modern democracies have created a form of masculinity that requires that male citizens carry the qualities of a warrior but remain capable of becoming a citizen once more at the conflict's end (Nye 2007, 417). The closing scene of the debut season shows Castle battling that duality when noting that what frightens him is not war, but its absence. As he admits to his veteran therapy group: "First time in as long as I can remember I don't have a war to fight. And I guess, if I'm gonna be honest ... I'm scared" (Surjik 2017).

\section{The Survivor}

Like Castle, Jessica Jones's titular lead departs from the standard superhero archetype. A modern spin on the noir detective, the series protagonist is a private investigator in New York, tailing adulterers, avoiding social connections, and drinking a lot of whiskey. But what sets Jones's story apart from the traditional comic superhero is neither her aversion to bearing the superhero mantle nor her superstrength. Rather, the Netflix 
series is unique for its focus on gender-based violence. The Jessica Jones we meet is a rape survivor.

Her attacker, Kilgrave, is the villain of the show's first season. A white man possessing the power to compel others through speech, his character was widely recognized as a commentary on "white, heteropatriarchal control," and the dangerous forms of grievance and entitlement it entails (Boyle 2020). His constant insistence that the women he targets smile, for example, is an eerie reminder of the small acts of control that underlie larger forms of gender-based violence. Kilgrave's villainy in fact follows the patterns of traditional abusers: he subjects Jones to physical and mental assault and manipulates her into feeling responsible for the pain he inflicts (Jeltsen 2105). We learn that Kilgrave forced Jones to act as his "lover" and turned her superstrength against others. In effect, Jones's superior physical abilities became Kilgrave's weapon; a woman who can lift cars with a finger was nevertheless subject to the abuses of a man she knows. At all times, the "trauma of [Jones's] vulnerability is still with her, as is her guilt about the crimes she committed at Kilgrave's behest" (Green 2019, 175).

The memory of Kilgrave's abuse constructs our introduction to Jones; his actions haunt her throughout the first season through flashbacks, dream sequences, and cleverly edited scenes that show him touching or whispering to her even though the audience knows he is not actually there. We feel Kilgrave's presence in his physical absence just as Jones does. Yet the series also upsets the voyeurism often found in cinematic representations of rape and abuse (Alcoff and Gray 1993). This occurs, first, by drawing attention to Jones's complex struggles with recovery in the aftermath of assault, and second, by creatively representing the "coercive control" that underpins abusive relationships (Green 2019, 176). In its focus on a supervillain whose power is fundamentally one of psychological manipulation, Jones's story critically foregrounds a discussion of sexual violence and the pathologies of interpersonal abuse.

\section{The Bulletproof Man}

As with Punisher and Jones, trauma and loss form the background to Luke Cage - though in this case those experiences are shaped by American racism. In the Marvel-Netflix iteration, Luke Cage is a wrongfully convicted former police officer sent to a high-security prison where he is tortured by guards; while incarcerated he becomes the subject of illegal experiments on inmates, after which he escapes prison. These experiments result in his superpowers: superstrength and indestructible skin.

Set in Harlem, Cage's story taps into the American prison industrial system and its racial bias, unethical medical experiments conducted on Black communities, and the unequal vulnerability of Black lives to harm. Outfitting Cage in a hoodie throughout the first season was a deliberate nod to the memory of slain teenager Trayvon Martin. For showrunner Cheo Hodari Coker, Cage's bulletproof skin cannot be read apart from America's racial state and the disproportionate risk it imposes on Black lives. With Cage, the series asks, "What if you introduce a bulletproof character into a social ecology that isn't bulletproof?" (Dockterman 2016).

The show's main villains are the criminal bosses of Harlem, Cornell Stokes (aka Cottonmouth) and Mariah Dillard (aka Black Mariah). But the writers link these villains to the criminal neglect of Black communities in America as a matter of government policy. As one of Stokes' enforcers comments, "This cat named Moynihan went and hollered at Nixon, and told the prez that maybe the inner city could benefit from the benign neglect" (Jobst 2016). With such references peppered throughout the show, Luke Cage intentionally calls out a history of redlining, economic disinvestment, and mass incarceration, practices that created the conditions that villains like Stokes and Dillard manipulate to their advantage. Of course, crime-ridden Gotham also shapes Batman, just as Metropolis's inability to curb the profit-mongering of men like Lex Luthor motivates Superman. But where these white men act as bulwarks for the state where it is unable to manage threats to the body politic, in the case of America's racial politics the state actively endangers Black communities. In the universe of Luke Cage, structural racism simultaneously enables Harlem's villains and sets up the need for heroes like Cage.

\section{Critical Interrogations, Suspended}

In each series, the protagonists are conditioned by broader structures of violence in American society; militarism (Punisher), gender-based violence (Jones), and racism (Cage) constitute the narrative conditions of and for violence. Coinciding with the rise of the \#MeToo movement, viewers lauded Jessica Jones's feminist ethos in taking issues of sexual violence seriously: In "the world of Marvel Comics, a female antihero-a female anything - is a step forward. But a rape survivor, struggling with P.T.S.D. (sic), is a genuine leap" (Nussbaum 2015). Similarly, Luke Cage was praised for giving American audiences a "symbolic representation of unapologetic black strength and resilience" (Williams 2017, 12). And reviews of The Punisher were almost universal in highlighting its engagement with toxic masculinity (Siede 2019), gun violence (Husband 2018), and military PTSD (Illing 2017).

But the interrogations of structures of violence and their effects we find in each series are suspended when it comes to the heroes' own expressions of violence. Though violence does constitute a tool that our three protagonists variously employ, their title to use it is differentially weighted by gender and race. Jones's heroic violence is curtailed, muted, and accompanied by reminders of gendered vulnerability. Cage's heroic violence is measured by his sacrifices to racialized expectations of respectability and control. In stark contrast to both, as The Punisher, Frank Castle is a white man consumed by violence and flanked by an unrestricted authority to use it. In Castle's hands, violence is a broadsword of justice, where for Jones and 
Cage violence must be employed with surgical precision. As the American state agents who have adopted him as an emblem realize, The Punisher understands himself to mark the line between good and evil they also see themselves enforcing.

\section{THREE MODES OF HEROIC VIOLENCE}

Given the series' active attempts to call out structures of harm and inequity, the gendered and racialized modes of violence each character is conditioned to use reveals the subtle yet troubling ways in which the privilege of violence operates in the American imaginary. It is to these modes that I now turn.

\section{Unrestricted}

Marvel Comics editor Steven Wacker estimated that since his 1974 introduction, The Punisher has killed around 48,502 people, a toll certainly increased by his Netflix run. But even as the series raises complex questions about militarism and trauma, and Castle's own 'broken' perspective, no "matter how many times The Punisher wants to debate Frank's morality, at the end of the day we're always going to be on his side" (Siede 2019). Explaining his popularity with audiences, David Sims (2016) of The Atlantic suggests that though we know Castle's actions are "indefensible, yet there's a simplicity to his philosophy that's hard to deny. Don't want to die? Don't be a criminal."

But there is more to Castle's appeal than the ostensibly simple philosophy his fans see. And there is more to trouble than the violent excesses The Punisher displays onscreen. The catalytic loss of Castle's family, even our willingness to judge his targets as criminal or to tolerate his gory brutality, would not be enough to render his character sympathetic-much less heroicto audiences were he not also a white man. That privileged violence is too easily masked by the "simplicity" Sims and others attribute to Castle's code irrespective of his identity. In comparative view, however, Castle's privileged violence is stripped bare.

Castle's experiences with trauma and loss enable a very different modality of violence than is afforded his Marvel compatriots Jessica Jones and Luke Cage. For instance, a repeated dream sequence involving Castle's wife and children evolves to become more and more violent: masked soldiers shoot first his wife and later his entire family, while he remains helpless to intervene. Difficult to watch, these scenes illustrate the power of Castle's despair. On one level, these dream sequences mirror how Jessica Jones is haunted by visions of her rapist, Kilgrave. For both Jones and Castle, the traumas they suffer revisit them again and again.

But in Castle's case, nightmares about his family linger in the background of scenes that show him systematically hunting down, torturing, and murdering the men who perpetrated that consequential act of violence. Indeed, the first three minutes of The Punisher's premier episode, "3AM," show Castle running down gang members with his car, shooting a cartel leader in Mexico, and murdering a mob boss in a public bathroom, and captures the immediate, explicit, and uncompromising character of his violence. Even when confronted with her rapist, we never witness Jones using similar forms of force. Rather, reminders of trauma modulate Jones's capacity for violence, but they validate Castle's. Noting that the people he fights will never stop, never care about society's laws (and ignoring his own affinity with them on precisely these points), Castle turns to his skull emblem and tells his friends: "let me be what I'm meant to be" (RichardsonWhitfield 2019). Despite his honest reflections about the effects of war and violence on his life at the end of the first season - of the ways in which these experiences helped to produce The Punisher - the series belies that complicated reality by ending with Castle presenting The Punisher as his "true" self: "this is always who I was."

\section{Vulnerable}

Just as The Punisher is introduced through Castle's unrestricted use of violence, the gendering of violence is made apparent in the premier episode of Jessica Jones, "AKA Ladies Night." The opening sequence in which Jones confronts an angry male client is viewed through the frosted glass of her front door. What we see is the shadow of the man yelling at her, before she throws him through the glass. Unlike the gory introduction to Castle's weaponized rage, we do not see Jones herself physically lifting and throwing her client through the door. Jones's strength is instead embodied through the body of the client, not her own.

A few minutes following this scene, Jones suffers a panic attack. Kilgrave looms by her side as he whispers in her ear, a hallucination that prompts her to recite street names from her childhood, a coping mechanism she uses to regain control. In other moments, Jones's use of violence is comically offset by depictions of her inebriated condition or ineffectual focus. These scenes efficiently suspend the nature of Jones's superpower and its destructive possibilities, first, by displacing a direct view of her violent acts and, second, by immediately drawing us back to her vulnerability. In effect, her displays of violence, however muted, must be followed by evidence of her continued exposure to Kilgrave's abuse. Her vulnerability hovers over even suggestions of her capacity for violence. As she insists after one breakdown, "I can't keep fighting him. I can't do this" (Jones 2015).

Jones's fear of being recaptured and put under Kilgrave's control is another reminder of her vulnerability. Remembering that Kilgrave once used her powers to harm other people turns Jones's "physical strength into his fetish" (Lickhardt 2020, 106). While Castle's military training becomes his resource as the Punisher, Jones's powers become a tool of Kilgrave's abuse. The effect of these narrative links between her strength and Kilgrave's abuse is to make female power and violence a resource for male harm. Her ever-present exposure to harm also cements Jones's desire to be, as it 
were, invisible, withdrawing from the world to stay hidden from her abuser. ${ }^{6}$ As she confesses to a friend, "I'm not safe anywhere, every corner I turn I'm not sure what's on the other side" (Clarkson 2015). Though we know she is capable of violence, and has cause to use it, her rare expressions of violence are either visually muted or comically framed, and they are always narratively followed by reminders of her susceptibility to male assault.

Notably, in the third and final season, the demand for a gendered performance of violence is upset by Jones's best friend Trish Walker, who through various plot developments has gained her own superpowers. But Walker, unlike Jones, becomes a vigilante of the style (if not the extent) of Frank Castle. A woman who herself suffered traumas as a child and adult, she exacts vengeance by taking the law into her own hands and summarily executing targets, something Jones never does. Walker thus fails to present the gendered vulnerability that attends Jones's use of violence in the series. The showrunners mark this "failure" by contrasting their characters. After a reluctant Jones is forced to capture her, Walker admits that she has become the "bad guy" (Hardiman 2019). Unlike The Punisher, Walker's pain and loss do not, in the end, validate her violence without the attendant vulnerability that Jones always displays.

\section{Sacrificial}

Where violence is unrestricted for Punisher or subject to vulnerability for Jones, Luke Cage's violence is marked by sacrifice. Drawing on Juliet Hooker's important analysis of the racial politics of democratic sacrifice, Luke Cage can be read as a text that assists in the "transmutation of black sacrifice into political exemplarity" (Hooker 2016, 450; see also: Phoenix 2019). However, Cage's sacrifice comes not through a disavowal of violence but in its conditional expression. That is how his performance of heroic violence as a superpowered Black man is legitimated.

Cage's use of force is visually constrained by small movements, a push or a shove, without resulting in the kind of visible damage we see Punisher produce. In this respect, there are some parallels to Jessica Jones, whose physical feats are also muted. But while Jones's violence is tethered to her vulnerability, Cage's violence is mitigated by the fact that he is simply never allowed to lose control even in the face of loss and harm. ${ }^{7}$ Cage's violence rarely encourages a view of "black anger and distrust as reasonable democratic responses" to the "agony of a racial democracy" (Lebron 2012). He in effect sacrifices justified rage

\footnotetext{
${ }^{6}$ My thanks to Nancy Hirschmann for raising the issues of invisibility and self-protection in comments on an earlier presentation of this argument.

${ }^{7}$ Indeed, for women of color and Black women in particular, even a performance of vulnerability might not be enough to legitimate their use of force to American audiences without additional caveats (Epstein, Blake, and González 2017).
}

over the harms he and his community suffer, to maintain the restraint demanded of his position as "Harlem's Hero."

Sometimes that control takes the form of contrition for having to engage in violent exchanges even when they are, arguably, warranted. In a pivotal episode, "DWYCK," (Shankland 2016), a hoodie-wearing Cage is confronted by cops while walking down the street, again being wrongfully profiled for a crime. This encounter is particularly noteworthy because it might have been a powerful illustration of racial bias in law enforcement. Yet, before preventing his wrongful arrest by physically throwing the officers across the street, Cage apologizes: "I'm really sorry guys." That apology might be benign if it were not also weighted by the clear allusions the scene makes to the acts of racial profiling that plague the daily lives of Black Americans. Centering his apology in what becomes a violent confrontation with law enforcement, the scene "gets the show's interrogations of racially charged shooting off to an awkward start" (Riesman 2016). Instead, the audience watches Cage forego his legitimate anger over being wrongfully targeted and admit culpability for the position the officers put him in. Cage's heroism is here premised on his ability to take responsibility, no matter the injustice he encounters.

With few exceptions too, the perpetrators of violent crime on the show are residents of Harlem. Of this, Christopher Lebron observes that while Luke Cage understands issues of poverty and neglect in Harlem to be "partly the consequence of institutional racism," the series still ties these inequities "to the greed expressed by two of its big bad black baddies, Black Mariah (Alfre Woodard) and Cottonmouth (Mahershala Ali)" (Lebron 2018). But the line between Black heroism and villainy is made to be quite thin by the series end, when we see Luke Cage flirt with the wider possibilities of violence and power. In the final season, Mariah Dillard insists that the difference between "gangster and sheriff" is flexible and to prove it deeds Cage Harlem's Paradise - the club at the center of Harlem's criminal activity and originally run by the now dead criminal boss Stokes (aka Cottonmouth). The audience last glimpses Cage out of his trademark hoodie and in a tailored suit surveying his new holdings, as a former Stokes enforcer relays information to him. Of this transition, showrunner Coker notes "If you immediately go from watching episode 13 of season 2 and go back to episode 1 of season 1, it's chilling how much Mike [Luke Cage] in that three-piece suit looks like Cottonmouth" (Li 2018).

By simply accepting the material power of his new position, Cage signals a flirtation with the narrative construction of the villain in the series. Meanwhile, Frank Castle's brutality never renders him the villain to audiences. As one of Castle's defenders suggests "we know better than most sometimes a criminal is a freedom fighter" (Surjik 2017). Such negotiated legitimacy is impossible for Cage. Viewed against The Punisher's unrestricted rage and Jessica Jones's gendered vulnerability, Luke Cage depicts the kind of violence 
American audiences, particularly white audiences, might accept of Black heroes, and expect of Black villains.

\section{RATIONALIZING HEROIC VIOLENCE}

Unrestricted rage, gendered vulnerability, and racial sacrifice constitute the three different modes of violence available to Castle, Jones, and Cage, respectively. These modes mark the organization of privileged violence through the different distributions of aggression, power, and legitimacy each affords. The characters' legibility as heroes depends on their adherence to that organizing schematic. But these modes of violence are also rationalized in very specific ways within the narrative framework of each series. Those rationalizations reveal the embeddedness of the privilege of violence in the American imaginary. Despite the critical interrogations of violence and of racial and gendered inequities intended by each series, all perform to that privilege through their protagonist's varied expressions of force.

\section{Inhibition vs. Drive: Violence and Self-Understanding}

The ways in which Castle understands his own violence conditions how the audience, too, is cued to justify it. In a confrontation with Lewis Walcott, a fellow veteran turned terrorist, Castle admits to him that "we are the same. We try to pretend that there's something more, something noble, Brother's-in-Arms right? We try to create a version of the world that we can stand to live in" (O'Hanlon 2017). What is truly remarkable about this statement is what Castle reveals to be the crux of his rage: his loss of place in the world and his title to reclaim it through violence. And it speaks directly to the sense of wounded subjectivity scholars have observed shaping a crisis of white masculinity in America (Gresson 2015)

Castle's admission contrasts starkly to Jones's selfunderstanding, which though also shaped by trauma, is bounded by a sense of inhibition. Media scholars have observed that the superhero genre has always had to negotiate "empowering female lives and bodies that seem liberating to girls and women, while not being threatening to boys and men (or, more broadly, patriarchal gender norms)" (Peppard 2017, 112). Gendering violence is a critical element of that negotiation. Jones's superior strength and capacities for violence are, as I have argued, made palatable because her vulnerability is always in view. Her character's violence is justified by the simultaneous adoption of norms concerning women's physicality and how it can, or ought to be, directed.

Jones's encounter with an antisuperhero vigilante, Audrey, is especially illustrative on this point. Audrey, who blames "supers" like Jones for the death of her mother, attempts to shoot Jones. For Jones, however, this incident becomes an opportunity to deny righteous anger and the violence it might justify. Rather than target Audrey, Jones proceeds to break items in the room, while making the following statement about what constitutes appropriate responses to loss and pain:

You think you're the only ones with pain, you think you can take your shit and dump it on me... .You take your goddamn pain and you live with it assholes. I don't work my shit out on other people. Keep your goddamn feelings to yourselves. (Petrarca 2015)

Jones's capacity for violence is here checked by her trauma; she "enacts her own body inhibition" throughout the show by deferring her rage, her strength, or turning it inward through feelings of guilt, shame, and fear (Young 1980, 153). A character written to deconstruct gendered narratives around physical and emotional decorum effectively reinscribes them through her person in the context of violence. And remarkably, though Jones does finally kill Kilgrave in the last episode of the first season, his death comes at great cost to her. It is only after Kilgrave has systematically targeted, tortured, and murdered a series of Jones's friends and allies that she is allowed to push aside her vulnerability and exact, in Castle's terms, justice. But she has to endure repeated abuse before accessing this final act of violence.

What for Jones is a last resort is, for Castle, the driving condition of his actions. Rooted in the intersecting privileges of masculinity and whiteness, Castle's violence is freed from the kind of performative inhibition that marks Jones's rage. Moreover, Castle's title to indiscriminate violence is accommodated by his unique relationship to the American state, one set into sharp relief when compared with the role of the state in Luke Cage.

\section{Repair vs. Revenge: Addressing the State and its Failures}

Viewers were quick to applaud Luke Cage's refusal to debate the politics of killing in the superhero genre. Whereas the debate over whether or not a superhero should kill forms a key part of Punisher, Daredevil, and Batman, "Cage doesn't kill, period, and he doesn't need a four-episode soliloquy to explain why" (Tassi 2016). Though intended as praise for narrative precision, this review misses that the white male protagonist of most other superhero stories has the luxury of debating an action that is not available to Cage. A Black man who kills is not legible as a hero in the American landscape. But one who sacrifices his legitimate rage and controls his violence enacts the racial exemplarity demanded by America's racial state. The distinctions between Cage and Castle's relation to the state bears narrative significance in real-life contexts, where Black protesters can be characterized as traitors and rioters alongside efforts to protect a militarized police system and its agents from reform.

Both The Punisher and Luke Cage showcase the failures of the state and its justice system, though 
neither of them directly challenges systemic corruption, or the institutions that betray them. However, where Cage steps in to repair the damage systemic racism creates in his community, Castle sees structural corruption as justification for his rage and attendant brutality. When the villain Stokes, for instance, warns Cage that taking Harlem from him "is expensive," Cage replies, "I don't want Harlem, I just want you to stop messing with it" (Jobst 2016). Not unlike other characters in the superhero canon, Cage's heroism is born not from a desire for fame or self-interest but from a sense of obligation to respond to the injustices neither the state nor society are equipped to correct (Blackmon 2017). This is a model display of citizenship.

But for Black superheroes, that display participates in what Rebecca Wanzo calls "melancholic patriotism," which addresses the ways in which "fantasies of US democracy can be built on the backs of those it uses and then discards" (Wanzo 2009, 341). In this sense, Cage's sacrificial justification for his own interventions into Harlem's criminal underworld belies the systemic injustice that the series makes note of in other respects. Ironically then, Cage's heroism is rationalized by foregrounding his responsibility to maintain peace within Black communities, but these are the very communities betrayed and actively imperiled by America's racial state.

Meanwhile, the same state that betrays Castle and is subject to his wrath repeatedly moves to protect him. The first season concludes with the government writing Castle a blank check for his actions as The Punisher: "You were betrayed, some kind of justice was done. And we hope that's enough for you" (Surjik 2017). In the face of a white man's fury, the American state accepts culpability and grants him immunity. And by the series end, in full view of his violent vigilantism, Castle is asked to work with the CIA. No such leniency is granted to Luke Cage whose efforts to protect Harlem and its people in the show's first season end with his arrest for escaping the prison in which he was tortured-the fact that he was wrongfully convicted notwithstanding.

Audiences are in fact primed for the state's protection of Castle by his friends, allies in law enforcement, and ordinary civilians, all of whom justify his actions throughout the series. Castle's fellow veteran and friend, Curtis Hoyle, insists that "Anybody that had anything to do with what happened to Maria and the kids are dead. Mission accomplished. And I don't have a problem with that" (Shankland 2017). Reporter Karen Page continually comes to Castle's defense and describes him as "Decent. Honest. He had a code and a sense of honor" (Walsh 2017). Even CIA Agent Madani, while investigating Castle's field unit in Afghanistan, treats Castle as an informant and ally in her effort to track institutional corruption. Conspicuously, Castle's friend Curtis Hoyle is a Black man, reporter Karen Page is a white woman, and Agent Madani is an Iranian American immigrant. These witnesses to his heroism seem intentionally diverse even though they themselves do not, and indeed cannot, participate in the kind of murderous "heroism" they defend in Castle.

\section{THE VIOLENCE WE CREATE}

The modes of violence I identify in these texts, combined with the politics of the superhero genre, forms the backdrop to the emergence of The Punisher as a symbolic reaction to Black Lives Matter and calls for reforming America's policing systems. Appropriations of the Punisher logo by American military and law enforcement officers are steeped in political and cultural meaning, a reality that ought to draw scholarly attention to the importance of popular culture as a site of politics. As a vigilante icon, Punisher's violence is shaped by grievance and an unchallenged sense of authority to confront the sources of his pain. That cops and military personnel turn to the Punisher icon when the abuses and biases of American security apparatuses capture the public eye makes apparent what Toni Morrison (2016) calls the "true horror of lost status" and the fierce drive to regain it. In fact, racial and gendered anxieties about white male status tap into a rather old idea in American politics - that of the Forgotten Man. Coined by William Graham Sumner in 1876, the term described "the victim of the reformer, social speculator and philanthropist" (Sumner 1918, 466). This appellation has enjoyed renewed attention in recent years, with white politicians including then candidate Trump claiming to stand for the forgotten man in ways that bring "the incipient racial and cultural inferences of forgotten-man rhetoric to the fore" (Glickman 2017).

In Punisher's case, that sense of social abandonment is fueled by feelings of loss - loss of family, status, and the stability both afforded this citizen-warrior. In these ways, Punisher's violence gets repackaged as an effect of the state and society's failures. Forgotten and alone himself, Castle's transformation into Punisher represents a rebellion against lost status; in his actions as judge, jury, and executioner, he effectively punishes both the state that betrayed him and the society from which he feels alienated.

Punisher's alienated status then helps solidify his transformation into a vigilante and to ascend "above all laws, all codes, but his own" (Johnston 2015; Palmer 2007, 195). Lorrie Palmer argues that the Punisher offers a new iteration of the hero of the Western noir: as a man apart, he operates with his own code of justice, which commits him to root out corrupt and villainous actors but necessitates his ostracism from society. But as argued, Castle's narrative also bears a unique connection to the state. As a soldier, Frank Castle was a tool of state violence. As The Punisher, he claims the state's monopoly over the use of violence for himself. It is no coincidence that The Punisher series is saturated with depictions of gun violence. The opening credits of the Netflix show conclude with an assortment of firearms coalescing to form the Punisher skull emblem. Castle's virtually unmediated access to guns is not only essential to his vigilantism; it also signifies his power to police the line between good and evil. 
In parallel ways, identifying with Punisher's pain and his reactionary violence against those he deems to be on the wrong side of his code, the officers who idolize him become themselves not perpetrators of violence against Black Americans but "the real victims" of "antipolice violence" (Hooker 2017, 495). With Morrison, Hooker notes that "White grievance, particularly the inability to accept loss (both material and symbolic) continues to be the dominant force shaping contemporary racial politics" $(2017,484)$. Gender, too, forms a critical part of that grievance, with white masculinity viewed as being "under attack" and in need of violent reinforcement. The Punisher's unique relationship to the state-defined by both law and lawlessnessmerges with the self-understanding of the state agents and their supporters who adopt his logo in the wake of calls for police reform and racial justice. Frank Castle's story symbolizes their anxieties about lost status and the rage that accompanies it.

The appearance of "Punisher cops" should draw critical attention in an era of increasingly militarized law enforcement cultures (Hinton 2016). In recently exposed training documents for the Kentucky State Police, cadets were instructed to "Be a loving father, spouse, and friend as well as the ruthless killer," and quotes from Mein Kampf and Confederate General Robert E. Lee were included to emphasize the utility of regularly employed violence (Peiser 2020). Like Frank Castle, the use of violence is here increasingly rationalized as a response to the "enemy within"-a battle fought not with foreign agents on foreign soil but against those at home who run afoul of the line between good and evil Punisher cops understand themselves to embody.

The Punisher thus represents the distribution of privileged violence venerated by security agents in their "war against those who hate law enforcement" (Clark 2019). Amidst fears of lost status, and a reinscription of calls for police reform as an attack on white male identity, The Punisher's unrestricted use of violence to "hold the line between good and evil" is symbolically appropriated in an insurgency against movements for social justice.

\section{Reflections from the American Imaginary}

My objective in this analysis is not to adulate an expansion of violence or to suggest that we should all be "Punishers" but to foreground the inequities that guide popular understandings of when, where, and by whom its use is justified. Those inequities address the different ways in which the privilege that attends violence in its intersections with gender and race is normalized even within the inventive space of the American imaginary. Though the fictional terrain of the superhero can reframe and contest the pathologies of different structures of violence in American society, the performance of violence retains a gendered and racialized caste in the creative spaces that actively try to interrogate these very inequities.

Though all our heroes must fight, how they fight is dependent upon the mode of violence they have title to enact. We recognize Jessica Jones's heroism because her gendered vulnerability to violence is made manifest. We recognize Luke Cage's heroism because it sacrifices justified rage to a performance of controlled violence and to a self-imposed responsibility to rectify the consequences of racial injustice. And we valorize Punisher's vigilantism not because his code is simple but because we are cued as an audience to rationalize his unrestricted violence, which is itself an expression of white male grievance. What these shows present for us is the ways in which the privilege of violence has been hardwired into the American imaginary, which is itself an instructive mirror for American society.

As argued, the different modalities of violence on view across these three shows provide an important framework for understanding ongoing appropriations of the Punisher character by state agents. Even though Castle's vigilantism places him outside legal and military structures, and also against the agents empowered by those structures, his actions as The Punisher have become a heroic symbol for American police officers and soldiers in their confrontations with challengersbe it in the context of American military operations abroad, as it was for Chris Kyle's unit in Iraq, or Black Lives Matter protesters at home. That is because as efforts to expose and reform the abuses and biases of America's policing structures gain traction, The Punisher emblem insists, "We're here and we're entitled to fuck with you." What Punisher symbolizes, in the end, is a vision of white masculinity maintaining control by exercising lethal authority over those who intend to subvert that control.

The Punisher now signals that vision in other venues too. Images of the black and white American flag with a blue line that defines the "Blue Line Punisher" favored by law enforcement and other variations of The Punisher skull appeared along with Confederate flags in Charlottesville and at Trump's rallies in the weeks leading up to the 2020 Presidential election (Chammah and Aspinwall 2020). And Punisher symbols were visible on the military-style gear worn by the armed mob that stormed the U.S. Capitol building on January 6, 2021 (McNamee 2021). Yet, in those few hours on the Hill, The Punisher also became a fraught symbol of white anxiety and anger-venerated by American security agents but adopted by the white civilians and veterans who attacked law enforcement at the Capitol by exercising the privilege of violence they all share. ${ }^{8}$ Indeed, the inability to perceive threats in the form of white bodies was evident in the failure to prepare for documented warnings of violence at the Capitol as well as the lax response thereafter (Gessen 2021), suggesting that the American security apparatus is primed not to police but to protect white grievance and rage. The implicit expectation of that protection is

\footnotetext{
${ }^{8}$ The fraught politics of privileged violence on view at the Capitol is further complicated by the "pain of policing while Black" and the racism Black officers on the Hill reported being subjected to, not only by insurrectionists but also by their white colleagues (Kaplan and Sapien 2021; Knowles and Beachum 2021).
} 
perhaps best illustrated by the lack of fear and even comic disdain displayed by the insurrectionists as they took selfies, attacked Capitol police, threatened congresspersons, and vandalized the premises-some doing so dressed as superhero characters.

Across these cases, that Punisher is a symbol being adopted by white men with power over the tools of violence speaks not only to the ways in which gender and race intersect to define Frank Castle as an iconic vigilante in American folklore. It is also a pointed reminder of the fact that the privilege of violence he exercises remains obstinately difficult to acknowledge much less to confront. Still, these appropriations of The Punisher have not gone entirely unchallenged. In the summer of 2020, as images of the Punisher skull appeared on law enforcement officers around the country during protests over racial injustice and police violence, the character's creator, Gerry Conway, launched a social media campaign to reappropriate the symbol for the Black Lives Matter Movement. In Conway's view, Punisher was always meant to serve as a reminder of social failure: "It always struck me as stupid and ironic that members of the police are embracing what is fundamentally an outlaw symbol." Conway suggested instead that that a new iteration of Frank Castle ought to tap into the condition of those most vulnerable to state-based violence and neglect. A new Punisher "could be Latino or black or Asian" (Voytko 2020).

But this assumes that the boundaries of violence in the American imaginary are more porous than they are in the American polity. Despite Conway's intentions for the character, or those of the Marvel-Netflix showrunners, The Punisher does enable the troubling appropriations we have seen. Castle's experiences with loss and betrayal reflect the self-understanding of his law enforcement followers as alienated state agents, and his response to that alienated status is one they enthusiastically identify with. As Punisher, Castle does not simply refute the state's monopoly on violence but claims it for himself, a claim strengthened by his unique relationship to the state as a white man. The advantages of that relationship are unavailable to the marginalized groups Conway imagines in a recasting of the character. As I have argued, their readability as heroes to an American audience depends upon their not engaging in the unrestricted violence Castle employs, but in turning instead to modified forms of force. The fact that each of the three series examined here takes pains to critically interrogate the costs and consequences of different structures of violence but nevertheless reinforce gendered and racialized modes of violence through their heroes, powerfully illustrates the obstacles that Conway's imaginative recasting of Punisher faces.

To envision these characters in ways which challenge those gendered and racialized boundaries will require a fundamental reconstruction of American identity on the ground. Though the playwright Bernard Shaw saw the imagination as the beginning of creation, in the context of violence the inventive possibilities of the American imaginary remain bounded by the complex power of white grievance and masculine rage. What the privilege of violence governing these popular works of imagination reveal then are both the symbolic and material challenges that America's ordinary heroes confront as they seek justice through political solidarity and resistance-even in the face of those who would punish them for doing so.

\section{ACKNOWLEDGMENTS}

I am grateful to Jennifer Forestal and to the participants at the Cornell Political Theory Workshop for their excellent feedback on earlier drafts. The article also benefitted from the insightful comments given by three anonymous $A P S R$ reviewers and the editors at APSR. Finally, my thanks to Geoff Dancy, who offered astute editorial notes on this piece, despite his aversion to superheroes.

\section{CONFLICT OF INTEREST}

The author declares no ethical issues or conflicts of interest in this research.

\section{ETHICAL STANDARDS}

The author affirms this research did not involve human subjects.

\section{REFERENCES}

Adams, Joshua. 2021. "The Falcon and the Winter Soldier Is Weird about Race." Colorlines, April 23. https:// www.colorlines.com/articles/falcon-and-winter-soldier-weirdabout-race.

Alcoff, Linda, and Laura Gray. 1993. "Survivor Discourse: Transgression or Recuperation?" Signs 18 (2): 260-90.

Anderson, Carol. 2016. White Rage: The Unspoken Truth of Our Racial Divide, 1st edition. New York: Bloomsbury US.

Asad, Talal. 2010. "Thinking about Terrorism and Just War." Cambridge Review of International Affairs 23 (1): 3-24.

Baldwin, James. 1962. "James Baldwin: Letter from a Region in My Mind.” New Yorker, November 17. https:/www.newyorker.com/ magazine/1962/11/17/letter-from-a-region-in-my-mind.

Balk, Tim. 2019. "St. Louis Police Union Asks Officers to Post Punisher Logo in Solidarity with Cops under Investigation." New York Daily News, July 12. https://www.nydailynews. com/news/national/ny-punisher-logo-st-louis-police-plain-viewproject-20190712-dcskdnuefvaw5kpvn63wbxf4r4-story.html.

Blackmon, Samantha. 2017. "'Be Real Black for Me': Lincoln Clay and Luke Cage as the Heroes We Need." CEA Critic 79 (1): 97-109.

Boyle, Amy. 2020. "My Favourite Detective: Jessica Jones, a SuperDetective for the Marvel Generation." The Conversation. December 21. http://theconversation.com/my-favourite-detectivejessica-jones-a-super-detective-for-the-marvel-generation-149542.

Braxton, Greg. 2019. "'Watchmen's' Provocative Portrait of Race in America Has Its Own Creator Worried." Los Angeles Times, October 20. https://www.latimes.com/entertainment-arts/tv/ story/2019-10-20/hbo-watchmen-damon-lindelof-regina-kingnicole-kassell.

Brown, Jeffrey. 2013. "Comic Book Masculinity.” In The Superhero Reader, eds. Kent Worcester, Jeet Heer, and Charles Hatfield, 269-78. Jackson: University Press of Mississippi. 
Buchanan, Larry, Quoctrung Bui, and Jugal K. Patel. 2020. "Black Lives Matter May Be the Largest Movement in U.S. History." The New York Times, July 3. https://www.nytimes.com/ interactive/2020/07/03/us/george-floyd-protests-crowd-size.html.

Burke, Liam, Ian Gordon, and Angela Ndalianis, eds. 2019. The Superhero Symbol: Media, Culture, and Politics. New Brunswick, NJ: Rutgers University Press.

Butler, Anthea. 2015. "Shooters of Color Are Called 'Terrorists' and 'Thugs.' Why Are White Shooters Called 'Mentally Ill?'”

Washington Post, June 18. https:/www.washingtonpost.com/ posteverything/wp/2015/06/18/call-the-charleston-churchshooting-what-it-is-terrorism/.

Campbell, Andy. 2017. "Kentucky Police Stop Using 'Punisher' Logo after Realizing What It Means | HuffPost.” HuffPost. February 28. https://www.huffpost.com/entry/kentucky-policepunisher-logo_n_58b1eed9e4b0780bac29f7c1.

Chammah, Maurice, and Cary Aspinwall. 2020. "Controversial 'Thin Blue Line' Flag Replaces America's 'Stars and Stripes' at Trump Rally in Waukesha." The Milwaukee Independent (blog) October 26. http://www.milwaukeeindependent.com/syndicated/ controversial-thin-blue-line-flag-replaces-americas-stars-stripestrump-rally-waukesha/.

Clark, Ed. 2019. "St. Louis Police Officer's Association Posts.” Facebook. July 10. https://www.facebook.com stlouispolice.officersassociation/photos a.337137543158388/1032113340327468/?type=3\& theater.

Clarkson, S. J. 2015. “AKA Crush Syndrome.” Jessica Jones. Netflix.

Coates, Ta-Nehisi. 2016a. "The Return of the Black Panther." The Atlantic, April. https://www.theatlantic.com/magazine/ archive/2016/04/the-return-of-the-black-panther/471516/.

Coates, Ta-Nehisi. 2016b. "Ta-Nehisi Coates Hopes 'Black Panther' Will Be Some Kid's 'Spider-Man,” NPR: Code Switch. April 6. https://www.npr.org/sections/codeswitch/2016/04/06/473224606/areluctant-king-ta-nehisi-coates-takes-on-marvels-black-panther.

Cohen, Jonathan. 2001. "Defining Identification: A Theoretical Look at the Identification of Audiences with Media Characters." Mass Communication and Society 4 (3): 245-64.

Costello, Matthew J., and Kent Worcester. 2014. "The Politics of the Superhero: Introduction." PS: Political Science \& Politics 47 (1): 85-9.

Cronin, Brian. 2020. “There's Not Much Marvel Can Do about Cops Using Punisher's Logo." CBR, June 7. https://www.cbr.com/ punisher-logo-marvel-cops-military-limited-legal-response/.

Dockterman, Eliana. 2016. "Behind 'Luke Cage,' The Most Political Superhero Show Yet." TIME.Com, September 17. https:// time.com/luke-cage-team/.

Dorzweiler, Nick. 2017. "Popular Culture in (and out of) American Political Science: A Concise Critical History, 1858-1950." History of the Human Sciences 30 (1): 138-59.

Eligon, John. 2014. "Michael Brown Spent Last Weeks Grappling with Problems and Promise." The New York Times, August 25. https://www.nytimes.com/2014/08/25/us/michael-brown-spentlast-weeks-grappling-with-lifes-mysteries.html.

Epstein, Rebecca, Jamila J. Blake, and Thalia González. 2017. "Girlhood Interrupted: The Erasure of Black Girls' Childhood." Washington, DC: Georgetown Law, Center on Poverty and Inequality

Fennessey, Sean. 2017. "The Superhero Movie Generation." The Ringer, November 13. https://www.theringer.com/ movies/2017/11/13/16643172/superhero-movies-2017-box-officefuture.

Fischel, Joseph J. 2017. "Horse F\#\$@ing and the Limits of Consent: What Broad City Teaches Us about Sexual Violence." Studies in Gender and Sexuality 18 (1): 31-4.

Galtung, Johan. 1969. "Violence, Peace, and Peace Research." Journal of Peace Research 6 (3): 167-91.

Gessen, Masha. 2021. "The Capitol Invaders Enjoyed the Privilege of Not Being Taken Seriously." The New Yorker, January 7. https:// www.newyorker.com/news/our-columnists/the-capitol-invadersenjoyed-the-privilege-of-not-being-taken-seriously.

Glickman, Lawrence B. 2017. "Forgotten Men." Boston Review, December 12. http://bostonreview.net/politics/lawrence-bglickman-forgotten-men-the-long-road-from-fdr-to-trump.

Green, Stephanie. 2019. "Fantasy, Gender and Power in Jessica Jones." Continuum 33 (2): 173-84.
Gresson, Aaron David. 2015. "Narcissism and White Pain: The White Male and the Masculinity Crisis - Again." Counterpoints 476: 59-90.

Grig, Lucy, ed. 2016. Popular Culture in the Ancient World. Cambridge: Cambridge University Press.

Hardiman, Neasa. 2019. “AKA Everything.” Jessica Jones. Netflix.

Haslem, Wendy, Elizabeth MacFarlane, and Sarah Richardson, eds. 2019. Superhero Bodies: Identity, Materiality, Transformation. New York: Routledge.

Hinton, Elizabeth Kai. 2016. From the War on Poverty to the War on Crime: The Making of Mass Incarceration in America. Cambridge, MA: Harvard University Press.

Hooker, Juliet. 2016. "Black Lives Matter and the Paradoxes of U.S. Black Politics: From Democratic Sacrifice to Democratic Repair." Political Theory 44 (4): 448-69.

Hooker, Juliet. 2017. "Black Protest/White Grievance: On the Problem of White Political Imaginations Not Shaped by Loss." South Atlantic Ouarterly 116 (3): 483-504.

Howard-Woods, Christopher, Colin Laidley, and Maryam Omidi, eds. 2017. \#Charlottesville: White Supremacy, Populism, and Resistance. New York: OR Books.

Husband, Andrew. 2018. "The Punisher and the Question of Gun Violence in America." Den of Geek, December 28. https:// www.denofgeek.com/tv/the-punisher-and-the-question-of-gunviolence-in-america/.

Illing, Sean. 2017. "The Punisher Is the Best Pop Culture Depiction of PTSD in America." Vox, December 11. https://www.vox.com culture/2017/12/11/16714526/marvel-the-punisher-ptsd-veterans.

Jeltsen, Melissa. 2105. “'Jessica Jones' Uses Superheroes to Expose the Terror of Domestic Abuse." HuffPost (blog). November 30. https:// www.huffpost.com/entry/jessica-jones-uses-superheroes-to-exposethe-terror-of-domestic-abuse n 565c9f47e4b079b2818b2b1d.

Jessica Jones. Created by Melissa Rosenberg, Netflix, 2015-2019.

Jobst, Marc. 2016. "Just to Get a Rep." Luke Cage. Netflix.

Johnston, Steven. 2015. American Dionysia Violence, Tragedy, and Democratic Politics. Cambridge: Cambridge University Press.

Jones, Simon Cellan. 2015. "AKA Top Shelf Perverts." Jessica Jones. Netflix.

Kaplan, Joshua, and Joaquin Sapien. 2021. "NNo One Took Us Seriously': Black Cops Warned about Racist Capitol Police Officers for Years." ProPublica, January 14. https:// www.propublica.org/article/no-one-took-us-seriously-black-copswarned-about-racist-capitol-police-officers-for-years?token= oJxRdpntIAw1xr06RcicsOZNwZWTLH3B.

Kendi, Ibram X. 2020. "The Violent Defense of White Male Supremacy." The Atlantic, September 9. https:// www.theatlantic.com/ideas/archive/2020/09/armed-defenderswhite-male-supremacy/616192/.

Knowles, Hannah, and Lateshia Beachum. 2021. "A Black Officer Died by Suicide, Leaving Anguished Videos. Another Officer Recognized His Pain." Washington Post, March 7. https:// www.washingtonpost.com/nation/2021/03/07/black-policeofficers-racism-protests/.

Kyle, Chris, Scott McEwen, and Jim DeFelice. 2013. American Sniper: The Autobiography of the Most Lethal Sniper in U.S. Military History. Reprint edition. New York: HarperCollins.

Lebron, Christopher J. 2012. "The Agony of a Racial Democracy." Theory \& Event 15 (3).

Lebron, Christopher J. 2018. “'Black Panther' Is Not the Movie We Deserve." Boston Review, February 16. http://bostonreview.net/ race/christopher-lebron-black-panther.

Lee, Stan. 2013. "More Than Normal, but Believable." In What Is a Superhero? eds. Robin S. Rosenberg and Peter M Coogan (Peter MacFarland), 115-18. New York: Oxford University Press.

Li, Shirley. 2018. "'Marvel's Luke Cage' Boss Breaks down 'Chilling' Season 2 Finale, Defends 13-Episode Seasons." EW.Com. June 22. https://ew.com/tv/2018/06/22/marvels-lukecage-boss-breaks-down-chilling-season-2-finale-defends-13episode-seasons/.

Lickhardt, Maren. 2020. "Threatening Gazes: Observation and Objectification in the TV Series Marvel's Jessica Jones." The Journal of Popular Television 8 (1): 105-19.

Luke Cage. Created by Cheo Hodari Coker, Netflix, 2016-2018.

McAllister, Matthew P., Edward H. Sewell, and Ian Gordon. 2001. Comics and Ideology. New York: Peter Lang. 
McCluskey, Martha T. 1992. "Privileged Violence, Principled Fantasy, and Feminist Method: The Colby Fraternity Case." Maine Law Review 44 (2): 261-313.

McNamee, Win. 2021. Congress Holds Joint Session to Ratify 2020 Presidential Election. Getty Images. https://www.gettyimages.ca/ detail/news-photo/protesters-enter-the-senate-chamber-onjanuary-06-2021-in-news-photo/1294932395?adppopup=true.

Morrison, Toni. 2016. "Making America White Again." The New Yorker, November 14. https://www.newyorker.com/ magazine/2016/11/21/making-america-white-again.

Nama, Adilifu. 2013. "Color Them Black." In The Superhero Reader, eds. Kent Worcester, Jeet Heer, and Charles Hatfield, 252-68. Jackson: University Press of Mississippi.

Nussbaum, Emily. 2015. "Jessica Jones: Graphic, Novel.” The New Yorker, December 14. https://www.newyorker.com/ magazine/2015/12/21/graphic-novel-on-television-emilynussbaum.

Nye, Robert A. 2007. "Western Masculinities in War and Peace." American Historical Review 112 (2): 417-38.

O'Hanlon, Jim. 2017. "Virtue of the Vicious." The Punisher. Netflix.

Oliphant, Baxter. 2017. "Views on White Advantages Break along Race, Party." Pew Research Center. https://www.pewresearch.org/ fact-tank/2017/09/28/views-about-whether-whites-benefit-fromsocietal-advantages-split-sharply-along-racial-and-partisan-lines/.

Palmer, Lorrie. 2007. “'Le Western Noir': The Punisher as Revisionist Superhero Western." In Amazing Transforming Superhero!: Essays on the Revision of Characters in Comic Books, Film and Television, ed. Terrence R. Wandtke, 192-208. Jefferson, NC: McFarland \& Company.

Peiser, Jaclyn. 2020. "Kentucky State Police Quoted Hitler and Encouraged Cadets to Be 'Ruthless' in a Training Program." Washington Post, November 2. https://www.washingtonpost.com/ nation/2020/11/02/kentucky-state-police-hitler-slideshow/.

Peppard, Anna. 2017. “This Female Fights Back!': A Feminist History of Marvel Comics." In Make Ours Marvel: Media Convergence and a Comics Universe, ed. Matt Yockey, 105-37. Austin: University of Texas Press.

Peppard, Anna. 2019. "When Comic Fans become Villains." The Walrus (blog). March 15. https://thewalrus.ca/when-comic-fansbecome-villains/.

Petrarca, David. 2015. “AKA 99 Friends.” Jessica Jones. Netflix. Phoenix, Davin L. 2019. The Anger Gap: How Race Shapes Emotion in Politics. Illustrated edition. Cambridge: Cambridge University Press.

Pippin, Robert B. 2010. Hollywood Westerns and American Myth: The Importance of Howard Hawks and John Ford for Political Philosophy. New Haven, CT: Yale University Press.

Rankine, Claudia. 2019. "I Wanted to Know What White Men Thought about Their Privilege. So I Asked." The New York Times, July 17. https://www.nytimes.com/2019/07/17/magazine/whitemen-privilege.html.

Richardson-Whitfield, Salli. 2019. "Flustercluck." The Punisher.

Riesman, Abraham. 2016. "Luke Cage's Take on Anti-Black Police Violence Is a Little Confusing." Vulture, October 3. https:// www.vulture.com/2016/10/luke-cage-police-brutalitystoryline.html.
Rogers, Melvin. 2020. "We Should Be Afraid, but Not of Protesters." Boston Review, May 29. http://bostonreview.net/race/melvinrogers-we-should-be-afraid-not-protesters.

Rojas, Rick, Richard Fausset, and Serge F. Kovaleski. 2020. "Georgia Killing Puts Spotlight on a Police Force's Troubled History." The New York Times, May 8. https://www.nytimes.com/2020/05/08/us/ glynn-county-police-ahmaud-arbery.html.

Schlam, Helena Frenkil. 2001. "Contemporary Scribes: Jewish American Cartoonists." Shofar 20 (1): 94-112.

Shankland, Tom. 2016. "DWYCK." Luke Cage. Netflix.

Shankland, Tom. 2017. "3AM." The Punisher. Netflix.

Siede, Caroline. 2019. "Is the Punisher's Critique of Toxic Masculinity Compelling or Hypocritical?" The A.V. Club. January 20. https://tv.avclub.com/is-the-punisher-s-critique-of-toxicmasculinity-compell-1831884784.

Sims, David. 2016. "The Disturbing Appeal of Jon Bernthal's Punisher in Netflix's 'Daredevil."” The Atlantic.” The Atlantic, March 24. https://www.theatlantic.com/entertainment/ archive/2016/03/the-disturbing-appeal-of-the-punisher/475188/.

Sumner, William Graham. 1918. The Forgotten Man and other Essays, ed. Albert Galloway Keller. New Haven, CT: Yale University Press.

Surjik, Stephen. 2017. "Memento Mori." The Punisher. Netflix.

Tassi, Paul. 2016. "Netflix’s ‘Luke Cage’ Is a Great Show Marred by a Terrible Third Act." Forbes, October 3. https://www.forbes.com/ sites/insertcoin/2016/10/03/netflixs-luke-cage-is-a-great-showmarred-by-a-terrible-third-act/.

The Punisher. Created by Steve Lightfoot, Netflix, 2017-2019.

Threadcraft, Shatema. 2016. Intimate Justice: The Black Female Body and the Body Politic. New York: Oxford University Press.

Vaughn, Justin S., and Lilly J. Goren. 2013. "The Mechanized Gaze: Gender, Popular Culture, and the Presidency." In Women and the White House, eds. Justin S. Vaughn and Lilly J. Goren, 1-22. Lexington: University Press of Kentucky.

Voytko, Lisette. 2020. "The Creator of 'The Punisher' Wants to Reclaim the Iconic Skull from Police and Fringe Admirers." Forbes, June 12. https://www.forbes.com/sites/lisettevoytko/2020/06/11/ the-creator-of-the-punisher-wants-to-reclaim-the-iconic-skullfrom-police-and-fringe-admirers/.

Walsh, Dearbhla. 2017. "Gunner." The Punisher. Netflix.

Wanzo, Rebecca. 2009. "Wearing Hero-Face: Black Citizens and Melancholic Patriotism in Truth: Red, White, and Black." The Journal of Popular Culture 42 (2): 339-62.

Watson, Amy. 2019. "Viewership of Marvel Superhero Movies by Age Group in the U.S. 2018." Media \& Advertising. Statista. https://www.statista.com/statistics/807367/marvel-movieviewership-age/.

Williams, J. Corey. 2017. "Luke Cage and Police Brutality." American Journal of Psychiatry Residents' Journal 12 (8): 12-12.

Williams, Zoe. 2018. "Jessica Jones: The Timely Return of a Feminist Superhero." The Guardian, February 24. https://

www.theguardian.com/culture/2018/feb/24/jessica-jones-mindcontrol-and-redemption-the-timely-return-of-a-feminist-superhero.

Young, Iris Marion. 1980. "Throwing like a Girl: A Phenomenology of Feminine Body Comportment Motility and Spatiality." Human Studies 3 (1): 137-56. 